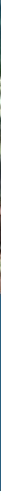

Mei 2007, No. 11 (

CIFOR infobrief memberikan informasi singkat, akurat dan telah dikaji-ulang tentang topik terkini dalam penelitian kehutanan

\title{
Hutan dan Kesehatan Manusia
}

Sekitar 350 juta orang tinggal di dalam atau di dekat hutan dan mereka tidak lepas dari berbagai penyakit dalam kehidupan sehari-hari. Penyakit seperti malaria, Ebola, kebutaan, demam, kaki gajah, dan berbagai penyakit lain diidap masyarakat yang hidup di daerah hutan. Seringkali, penyakit tersebut tumbuh subur saat hutan berada dalam kondisi rusak atau ditebang habis.

Hubungan antara kesehatan manusia dan hutan tropis merupakan hubungan yang sangat rumit dan dipengaruhi oleh berbagai faktor, termasuk pola makan, kemiskinan, perubahan iklim, dan kegiatan pemanfaatan lahan. Sebuah laporan CIFOR baru-baru ini mengungkapkan berbagai cara bagaimana hutan tropis mempengaruhi kesehatan manusia, baik yang tinggal di dalam atau di luar hutan. Infobrief ini memberikan rangkuman singkat mengenai hal tersebut.

\section{Isu utama}

- Hutan tropis menyediakan pangan, obat-obatan, dan bahan bakar bagi jutaan manusia. Namun ada sisi yang tidak menguntungkan bagi kehidupan manusia yang tinggal di hutan: banyak dari mereka terkena penyakit yang parah dan seringkali fatal. Penebangan hutan yang dilakukan dengan bijak kadang-kadang dapat memperbaiki kehidupan, misalnya bila hutan diubah menjadi ladang atau kebun yang produktif. Namun, deforestasi, selain menyebabkan masalah-masalah lingkungan, juga menyebabkan hilangnya pangan alami dan mendorong penyebaran penyakit.

- Penyakit yang bermula dari hutan - contoh nyatanya adalah HIV/AIDS - dapat menyebar ke daerah sekitarnya. Demikian pula halnya dengan penyakit yang berasal dari luar wilayah hutan dapat memberikan dampakyang serius bagi penduduk hutan.

- Perubahan iklim secara nyata dapat mempengaruhi ketersediaan pangan dan tumbuhan obat-obatan yang berasal dari hutan di masa datang. Perubahan iklim juga dapat memicu peningkatan berbagai penyakit di wilayah hutan.

- Masyarakat yang tinggal di hutan seringkali tidak terjangkau oleh layanan kesehatan. Tidaklah mungkin untuk mendatangkan praktisi kesehatan yang terlatih ke setiap desa. Pemecahan masalahnya terletak pada upaya-upaya yang sifatnya lintas disiplin yang menggabungkan sistem penyembuhan tradisional dengan pemeliharaan kesehatan modern.

\section{Hutan dan sumber pangan}

Meskipun seringkali tidak cocok bagi kegiatan pertanian konvensional, hutan merupakan sumber bahan makanan yang kaya bagi masyarakat setempat. Hutan merupakan sumber kacang-kacangan, buah-buahan, perdu, akar, jamur, dan hewan dengan berbagai ukuran, mulai dari kumbang kelapa hingga gajah. Banyak jenis yang hidup di hutan memiliki kandungan gizi seperti vitamin A dan C, niasin, dan zat besi, yang merupakan unsur penting bagi kesehatan. Hutan juga menyediakan bahan makanan bagi ternak, dan di banyak negara hutan merupakan sumber kayu bakar untuk memasak. Di masa depan, hutan mempunyai potensi untuk menyediakan lebih banyak makanan melalui pemuliaan tanaman pangan terseleksi, atau melalui upaya yang lebih kontroversial, yaitu dengan rekayasa genetis.

Karena hutan dapat menyediakan bahan pangan saat situasi perang dan paceklik, hutan dapat berperan sebagai jaring pengaman. Namun demikian, hutan dapat pula menjadi perangkap kemiskinan karena masyarakat penghuni hutan sering tersisih dari proses pembangunan dan sulit bagi mereka untuk mencari nafkah. Hal ini berarti mereka sangat tergantung pada hutan sebagai sumber bahan pangan. Kenyataan ini kemudian dapat memicu eksploitasi terhadap jenis bahan pangan yang memberikan implikasi serius bagi hidupan liar dan manusia. Perburuan komersial untuk

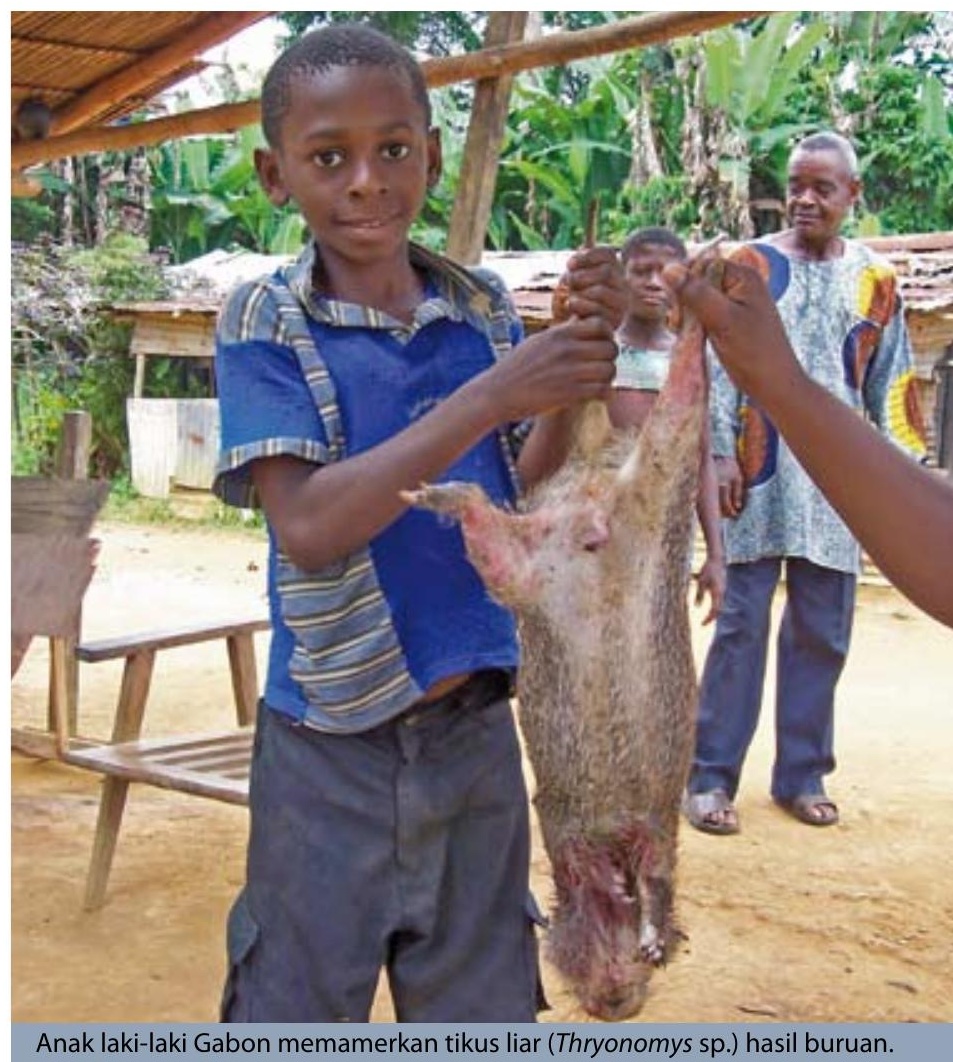

Di Gabon jenis tikus ini menjadi bahan makanan (foto oleh Carol J.P. Colfer) 


\section{Nutrisi dan kesehatan jasmani di antara kelompok Punan di Kalimantan Timur}

Tekanan yang kuat kepada kelompok masyarakat yang hidup nomaden untuk tinggal menetap tidak selalu membawa perbaikan yang dijanjikan terhadap kondisi asupan dan kesehatan mereka. Edmond Dounias dan rekan-rekannya membandingkan tingkat asupan dan nutrisi dari tiga kelompok masyarakat yang dulu merupakan pemburu dan pengumpul yaitu suku Punan di Kalimantan. Ketiga kelompok ini telah mengadopsi sistim pertanian gilir balik sejak hampir enam dekade lalu. Kelompok ini memiliki tingkat ketergantungan yang berbeda terhadap pertanian dan hasil hutan, tergantung pada tingkat aksesbilitas mereka ke wilayah perkotaan.

Kelompok Punan yang lebih terpencil, mempunyai asupan yang lebih bervariasi dan mempunyai kondisi nutrisi serta kesehatan yang lebih baik. Kontribusi dari sumberdaya hutan terhadap asupan mereka juga menurun dengan semakin dekat jarak ke kota. Ketergantungan terhadap pertanian bukan merupakan penyebab langsung terhadap menurunnya asupan dan kesehatan, tetapi lebih karena transisi dari pola hidup berpindah ke menetap.

Para penulis menyimpulkan bahwa "perubahan yang drastis dalam gaya hidup kelompok-kelompok Punan di Kalimantan sangat mempengaruhi integritas suku ini dan berdampak terhadap segisegi sosial, budaya, simbolik dan politik mereka."

Sumber: From sago to rice, from forest to town: The consequences of sedentarization for the nutritional ecology of Punan former hunter-gatherers of Borneo oleh Edmond Dounias, Audrey Selzner, Miyako Koizumi dan Patrice Levang. 2007.

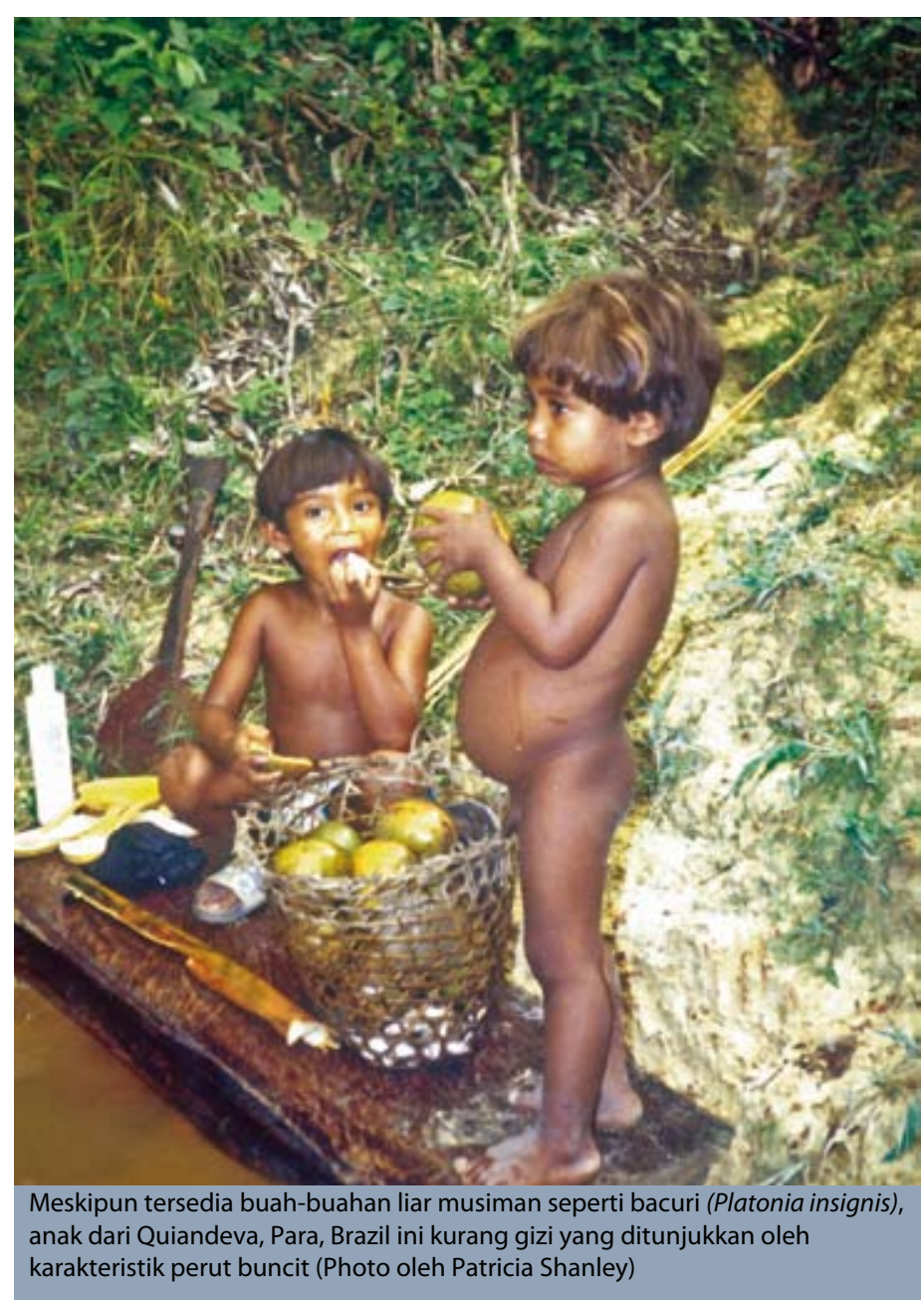

memenuhi permintaan pasar di wilayah urban dan pasokan kegiatan penebangan kayu juga mengancam populasi hidupan liar di sejumlah besar negara-negara tropis. Sebagai contoh, perdagangan daging hidupan liar di Kamerun dan Gana menyebabkan turunnya populasi primata dan hewan berkuku dua di banyak wilayah.

Sebagian bahan pangan dari hutan dapat mengancam kesehatan manusia. Akar-akaran tropis seperti singkong, yang mengandung sedikit sianida, beracun bila tidak dimasak dengan baik. Selain itu, racun aflatoksin yang bersifat karsinogenik biasanya terkait dengan jagung dan bahan makanan lain yang terkontaminasi oleh jamur. Penanganan daging hidupan liar dapat menyebabkan penyebaran penyakit yang disebabkan oleh virus.

Ketahanan pangan - yaitu memiliki cukup bahan makanan - merupakan masalah serius di wilayah hutan. Selain itu, ketersediaan bahan pangan dari alam yang berfluktuasi secara musiman dapat memicu daur kelimpahan dan kekurangan. Distribusi pangan yang tidak merata dalam keluarga sering menyebabkan, terutama bagi para ibu dan anak perempuan, resiko kekurangan gizi dan dengan demikian lebih rentan terhadap penyakit. Perempuan dan anak-anak juga memiliki kemungkinan yang lebih tinggi untuk mengidap penyakit pernafasan parah yang disebabkan oleh kegiatan memasak dengan kayu bakar.

\section{Hutan dan penyakit}

Penyakit tropika mempengaruhi setengah milyar orang dan mematikan sekitar 20 juta orang setiap tahunnya. Sebagian besar penyakit ini mempengaruhi penduduk yang tinggal di hutan dan keberadaan penyakit ini seringkali dipengaruhi oleh deforestasi, kegiatan pertambangan, pembangunan bendungan, dan kegiatan lainnya.

Malaria, yang disebarkan oleh nyamuk, merupakan pembunuh utama di negara-negara tropis. Pernah pada satu saat sekitar 500 juta orang menderita penyakit malaria, 70 persen dari kasus tersebut terjadi di Afrika. Keterkaitan antara penyakit dan hutan merupakan hubungan yang rumit. Di Nepal dan Panama, pembabatan hutan memungkinkan populasi manusia untuk menempati daerah yang sebelumnya tidak mungkin ditinggali karena malaria. Namun demikian, eksploitasi hutan juga dapat menyebabkan peningkatan penyakit malaria, terutama saat kegiatan penebangan kayu menimbulkan genangangenangan air tempat nyamuk berkembang biak.

HIV/AIDS merupakan penyakit yang bersumber dari hutan, dalam arti bahwa virus yang berpindah dari simpanse ke manusia di Afrika Tengah. Karena ditularkan melalui kontak seksual, HIV/AIDS tidak mengenal batas geografis. Penyakit ini telah mematikan lebih dari 25 juta orang, terutama di Afrika, dan telah menghancurkan ekonomi berbagai negara di Sub-Sahara. Kemiskinan, imigrasi, prostitusi, perkosaan sebagai perangkat perang, dan faktor lain merupakan penyebab utama penyebaran HIV/AIDS. Di wilayah hutan, pembangunan jalan bagi kegiatan penebangan kayu dan pertambangan merupakan "perangkat" penyebar penyakit ini ke tempat-tempat terpencil.

Sejumlah penyakit terkait secara erat dengan penurunan kualitas ekologi dan hilangnya hutan (Lihat Tabel 1). Di Afrika, penyakit tersebut antara lain adalah Ebola, demam kuning, dan kebutaan yang disebabkan 


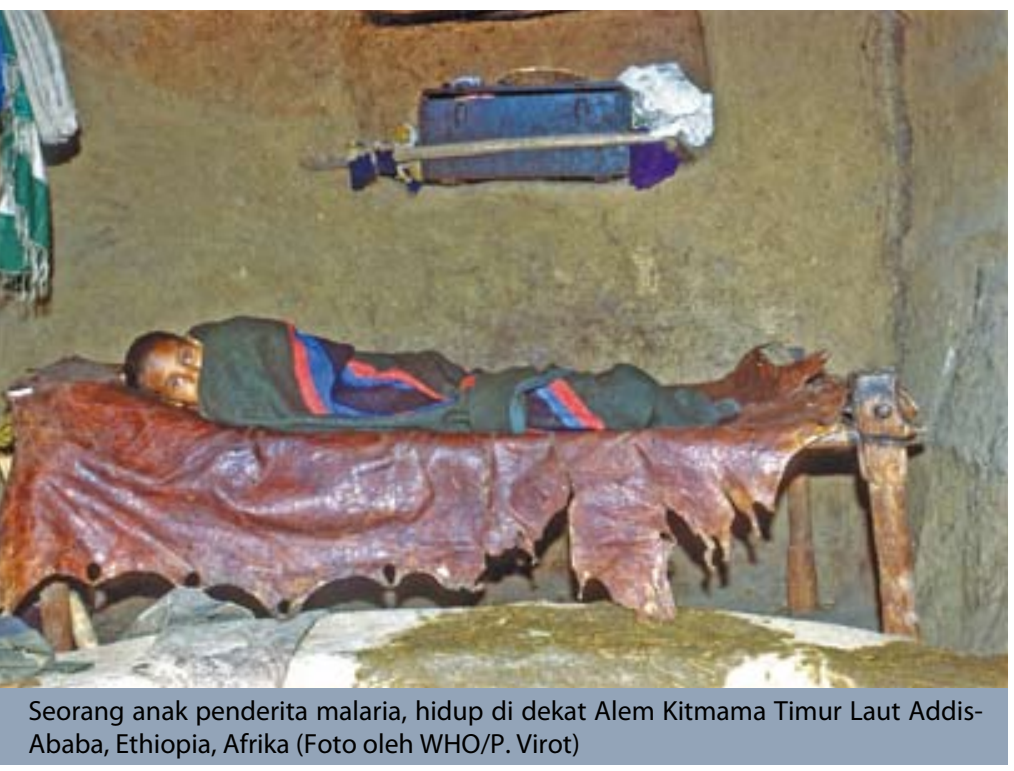

\section{HIV/AIDS di Kalimantan Barat}

Jumlah penderita HIV/AIDS di Kalimantan Barat telah mencapai 294 pada bulan Mei 2005. Dari jumlah tersebut 36 telah meninggal dunia. Perwakilan dari United Nation Population Fund (UNFPA), Dr. Bernard Coquelin, mengatakan bahwa masyarakat harus bekerjasama dalam mengurangi jumlah penderita HIV/AIDS. Dr. Bernard juga menyarankan lembaga-lembaga pemerintahan, termasuk DPRD untuk mendukung program pencegahan HIV/AIDS yang dibentuk oleh Perkumpulan Keluarga Berencana Indonesia (PKBI). Sementara itu, Kepala Badan Koordinasi Keluarga Berencana Nasional (BKKBN) Kalimantan Barat, Faozan Alfikri, menyatakan pada 8 September 2006 bahwa ada kira-kira 2.972 - 4.799 orang yang terinfeksi HIV/AIDS di propinsi Kalimantan Barat.

Sumber: http://www.bkkbn.go.id/article_detail.php?aid=380

sejenis cacing filaria (onchocerciasis). Di Amerika Selatan, pembabatan hutan yang dilakukan untuk peternakan sapi menyebabkan peningkatan populasi kelelawar vampir secara dramatis. Kelelawar ini merupakan tempat tinggal alami penyakit rabies. Penyakit Chagas diungkapkan memiliki keterkaitan dengan imigrasi dan pembabatan hutan. Pembangunan bendungan dan irigasi di wilayah hutan menyebabkan peningkatan penyakit malaria, penyakit cacing "guinea", demam berdarah dan pes.

Banyak wilayah hutan yang kaya akan mineral, dan kegiatan pertambangan mempengaruhi kesehatan penduduk setempat dalam berbagai hal. Sebagai contoh, pertambangan emas sering dikaitkan dengan insiden keracunan merkuri, yang menurunkan ketahanan tubuh terhadap penyakit dan dapat menyebabkan kegilaan. Merkuri digunakan dalam pemrosesan emas dan banyak ditemukan dalam kadar tinggi yang berbahaya dalam aliran air dan ikan di Amazonia, Filipina, dan di berbagai tempat lainnya.

Eksploitasi mineral, kayu, dan sumberdaya alam yang lain secara umum berkaitan dengan perpindahan manusia keluar dan masuk wilayah hutan. Penduduk yang tinggal di luar hutan menularkan penyakit kepada penduduk yang tinggal di dalam hutan yang memiliki ketahanan yang rendah, atau bahkan tidak memiliki ketahanan sama sekali, terhadap penyakit tersebut. Sebaliknya, para pendatang dapat terjangkit penyakit yang bersumber dari hutan untuk pertama kalinya. Hal ini menyebabkan peningkatan resiko kesehatan bagi kedua populasi tersebut. Bukti-bukti menunjukkan bahwa pada saat hutan ditebang untuk pertanian dan peternakan, kesehatan penduduk yang hidup di hutan pada umumnya mengalami gangguan, setidaknya dalam jangka pendek.

\section{Hutan dan obat-obatan}

Sebuah survei terhadap 150 jenis obat beresep yang umum digunakan di Amerika Serikat menunjukkan bahwa 57 persen mengandung sedikitnya satu senyawa aktif yang didapat dari alam. Sebagian besar di antaranya didapat dari hutan tropis, antara lain adalah senyawa kontrasepsi, pengendur otot, senyawa anti bakteri, aprodisiak, dan obatobatan yang digunakan untuk mengobati gagal jantung, malaria, kanker, dan penyakit lainnya.

Penduduk asli di hutan tropis memiliki pengetahuan yang luar biasa tentang tumbuhan obat-obatan, dan di sejumlah besar wilayah penyembuh tradisional merupakan penyedia jasa pelayanan kesehatan yang utama. Bukti kemampuan pengobatan tradisional makin berkembang, dan tumbuhan obat-obatan dari wilayah tropis kini digunakan di seluruh dunia.

Permintaan tumbuhan obat-obatan yang terus meningkat ini menyebabkan sekitar setengah dari 20.000 jenis tumbuhan yang digunakan terancam punah. Contohnya, populasi tumbuhan Prunus africana yang kulit kayunya digunakan untuk mengobati masalah prostat, turun secara dramatis di Kamerun. Cerita serupa terjadi pula pada berbagai jenis tumbuhan yang lain.

Ada sejumlah besar kontroversi mengenai pemanenan tumbuhan obat-obatan untuk pasokan industri farmasi.

\section{Tabel 1. Penyakit utama dan kaitannya dengan hutan}

\begin{tabular}{l|l}
\hline $\begin{array}{l}\text { Penyakit yang terkait dengan } \\
\text { deforestasi atau kerusakan } \\
\text { ekologis }\end{array}$ & $\begin{array}{l}\text { Penyakit yang terkait dengan } \\
\text { pembangunan bendungan, } \\
\text { irigasi, atau lahan pertanian }\end{array}$ \\
\hline Penyakit Chagas & Demam berdarah \\
\hline Demam berdarah & Dracunculiasis (Cacing "Guinea") \\
\hline Virus Ebola & Leishmaniasis \\
\hline Penyakit hutan Kyasanur & Lymphatic filariasis (kaki gajah) \\
\hline Virus Lassa & Malaria \\
\hline Leishmaniasis & Pes \\
\hline Loa loa & Schistosomiasis \\
\hline Malaria & \\
\hline Virus Marburg & \\
\hline $\begin{array}{l}\text { Onchocerciasis (Kebutaan yang } \\
\text { disebabkan oleh cacing filaria) }\end{array}$ & \\
\hline Demam Oropouche & \\
\hline Pes & \\
\hline Rabies & \\
\hline Schistosomiasis & \\
\hline Demam kuning & \\
\hline
\end{tabular}

Sumber: Colfer et al. 2006. Forests and human health: Assessing the evidence, Tabel 4. CIFOR, Bogor, Indonesia. 


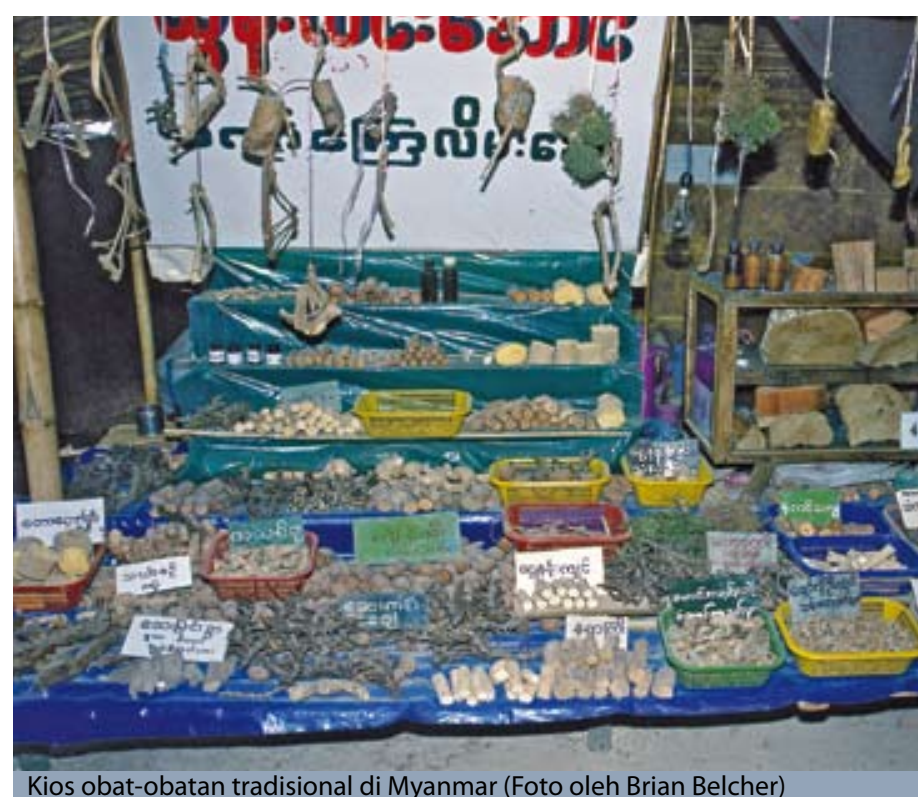

\section{Hutan dan tumbuhan obat}

Hutan di Bukit Siketan, Desa Baru Pelepat, Jambi menyimpan berbagai jenis tumbuhan obat. Dua di antaranya menjadi bahan penting bagi industri farmasi baik di dalam mau pun di luar negeri, yaitu pasak bumi (Eurycoma longifolia) yang juga dikenal di Malaysia dan Vietnam, dan akar kait (Uncaria spp.) yang digunakan di Amerika Latin dan Asia.

Bila masyarakat membudidayakan tumbuhan obat di kebun masing-masing, mereka dapat meningkatkan kesehatan keluarga (TOGA = Tanaman Obat Keluarga). Dengan membangun jaringan pemasaran dengan industri obat alami/herbal, budidaya tanaman obat juga berpotensi menjadi sumber pendapatan alternatif.

Sumber: Yuliani, E.L., Anggana, Novasyurahati. Akan terbit. Kekayaan hutan Bukit Siketan. Dalam: Adnan dkk. (Eds). Bunga rampai penelitian di Kabupaten Bungo. CIFOR, Bogor, Indonesia.

Masyarakat yang hidup di hutan, seperti sering diungkapkan, tidak mendapatkan kompensasi yang memadai, baik untuk pengetahuan mereka maupun bagi tumbuhan yang dipanen. Perusahaan obat-obatan umumnya enggan untuk berbagi informasi mengenai kegiatan mereka, dan enggan untuk bekerjasama dengan masyarakat lokal ketika eksplorasi obat-obatan baru membuahkan hasil.

\section{Hutan dan kebudayaan}

Kebudayaan, sangat beragam dan berbeda dari satu tempat ke tempat lainnya; tetapi kebudayaan dapat berubah, dan manusia selalu berubah. Namun demikian, manusia - baik yang tinggal di pedalaman hutan atau di kota metropolitan yang ramai - terjalin dengan dan tergantung pada kebudayaan demi kesejahteraan kehidupan mental dan sosial mereka. Secara umum, perubahan budaya yang cepat dan tidak terkendali cenderung berdampak buruk pada kesehatan manusia dan lingkungan.

Hal inilah yang terjadi pada sejumlah besar masyarakat yang hidup di hutan. Berbagai penelitian menunjukkan bahwa pembangunan yang cepat - contohnya yang disebabkan oleh pembukaan hutan bagi pertambangan, pengambilan kayu, dan pertanian - dapat meningkatkan kondisi depresi dan putus asa serta hilangnya kearifan lokal dan sumberdaya yang penting.

Komunikasi yang efektif dengan penduduk hutan menuntut pemahaman dan penghargaan terhadap pandangan hidup mereka. Pengetahuan lokal tentang makanan dan obat-obatan tidak diragukan lagi sangat bermanfaat bagi para profesional di bidang kesehatan Barat. Sama pentingnya adalah bahwa pengakuan yang lebih baik terhadap nilai pengetahuan lokal dapat menimbulkan rasa percaya diri dari penduduk hutan tersebut. Kondisi ini memiliki implikasi positif terhadap kesehatan mental mereka.

\section{Bagaimana memperbaiki kesehatan masyarakat yang hidup di hutan?}

Para praktisi pelayanan kesehatan dapat belajar lebih banyak tentang kebutuhan kesehatan bagi masyarakat yang tinggal di hutan dan memperluas pelayanan kesehatan ke dalam wilayah hutan. Para ahli ini dapat memberikan saran mengenai kebersihan dan pola makan, dan mendorong mereka untuk mengurangi konsumsi ikan dari sungai yang terkontaminasi oleh merkuri dan bahan pencemar lainnya. Para ahli juga dapat menyediakan informasi untuk menghindari bahaya HIV/AIDS dan informasi mengenai potensi bahaya yang ditimbulkan melalui kontak antara hidupan liar dan manusia.

Sistem kesehatan tradisional yang dipraktekkan oleh penyembuhtradisional dapat digunakanuntukmemperbaiki kesehatan masyarakat bila para penyembuh tradisional dan profesional kesehatan bersama-sama menggabungkan sistem pelayanan kesehatan tradisional dan modern.

\section{Hutan, air dan kesehatan manusia}

"Sejakbanyakpenebangan hutan dan pembangunan jalan di hulu, jika turun hujan, air sungai langsung jadi keruh. Untuk masak dan minum, air sungai harus diendapkan dulu. Setelah diendapkan, tanahnya bisa sampai setengahnya. Kalau dipakai mandi, badan malah gatal-gatal dan jadi penuh tanah," demikian keluhan masyarakat di sepanjang Sungai Leboyan di kawasan Taman Nasional Danau Sentarum (TNDS), Kalimantan Barat.

Masyarakat di TNDS sepenuhnya menggantungkan kebutuhan air dari danau dan sungai. Illegal logging yang sangat marak di tahun 2000-2005 di kawasan ini telah menyebabkan erosi dan pelumpuran, dan akibatnya sungai-sungai menjadi keruh berlumpur di musim hujan. Pengukuran kekeruhan air di musim hujan menunjukkan nilai 7-16 NTU, jauh di atas ambang batas untuk kesehatan manusia yaitu 5 NTU. Tanpa pelumpuran, tingkat kekeruhan di kawasan ini $0,1-0,8$ NTU.

Musim kemarau tidak berarti terbebas dari masalah. Debit air sungai di musim kemarau dalam beberapa tahun terakhir menurun drastis, dan masyarakat menduga hal ini disebabkan hilangnya hutan di daerah hulu. Turunnya debit air diiringi meningkatnya populasi manusia dan kegiatan MCK (Mandi Cuci Kakus) karena datangnya orang luar yang menangkap ikan. Akibatnya, banyak masyarakat yang menderita sakit kulit dan gangguan pencernaan. "Ketika hutan masih bagus, air sungai di musim kemarau tidak sekering ini," kata seorang ibu di Desa Nanga Leboyan.

Oleh: E. Linda Yulian 


\section{Pencemaran merkuri dari darat ke sungai}

Masalah pencemaran raksa (merkuri) di Kalimantan Tengah semakin meningkat, karena limbah dari kegiatan tambang tradisional terus menerus mengalir ke sungai-sungai besar.

Sungai dengan kondisi terparah adalah Sungai Kahayan, dengan jumlah raksa yang terbuang mencapai 1,5 ton dalam waktu tiga bulan. Kandungan raksa dalam ikan yang ditemukan di sana rata-rata 0,22 bpj, jauh di atas batas normal yang ditentukan Dewan Pengawas Obat dan Makanan (DPOM), yaitu 0,04 bpj.

Sebagian besar kandungan raksa yang terlepas dari proses penambangan melekat pada sedimen dan sebagian lagi berubah menjadi raksa organik yang bersifat sangat membahayakan fungsi pernafasan dan sistem metabolisme. Jenis siput dan udang kecil akan menyerap raksa organik ini dari endapan dan air. Ikan yang memakan udang dan siput atau ikan yang terkontaminasi akan mengakumulasi raksa organik dalam tingkat yang tinggi.

Para penambang di lapangan tercemar raksa melalui kontak langsung dengan kulit, menghirup asap raksa, dan memakan ikan yang telah tercemar raksa. Untuk masyarakat umum, pencemaran biasanya terjadi karena memakan ikan yang telah tercemar dan menghisap asap raksa yang berasal dari toko emas di sekitarnya ketika amalgam dibakar. Masalah kesehatan utama akibat uap raksa terjadi pada otak, paru-paru, sistem saraf pusat dan ginjal.

lbu yang sedang hamil dapat menularkan raksa organik pada janin melalui plasenta sehingga merusak otak dan organ tubuh janin dan menyebabkan keterbelakangan, bahkan kematian. Bayi dan anak kecil yang terkontaminasi raksa dapat mengalami kesulitan belajar atau tingkat kecerdasan yang rendah di kemudian hari.

Ada beberapa cara untuk mengurangi limbah raksa yang dihasilkan kegiatan tambang tradisional. Diantaranya adalah menggunakan sistem tertutup ketika melakukan proses amalgamasi untuk mengurangi jumlah raksa yang terbuang ke tanah dan udara.

Sumber: Pencemaran merkuri dari darat ke sungai oleh Yuanita Oktaviana, Rumah Emas Kita, Edisi 01 Agustus 2006.

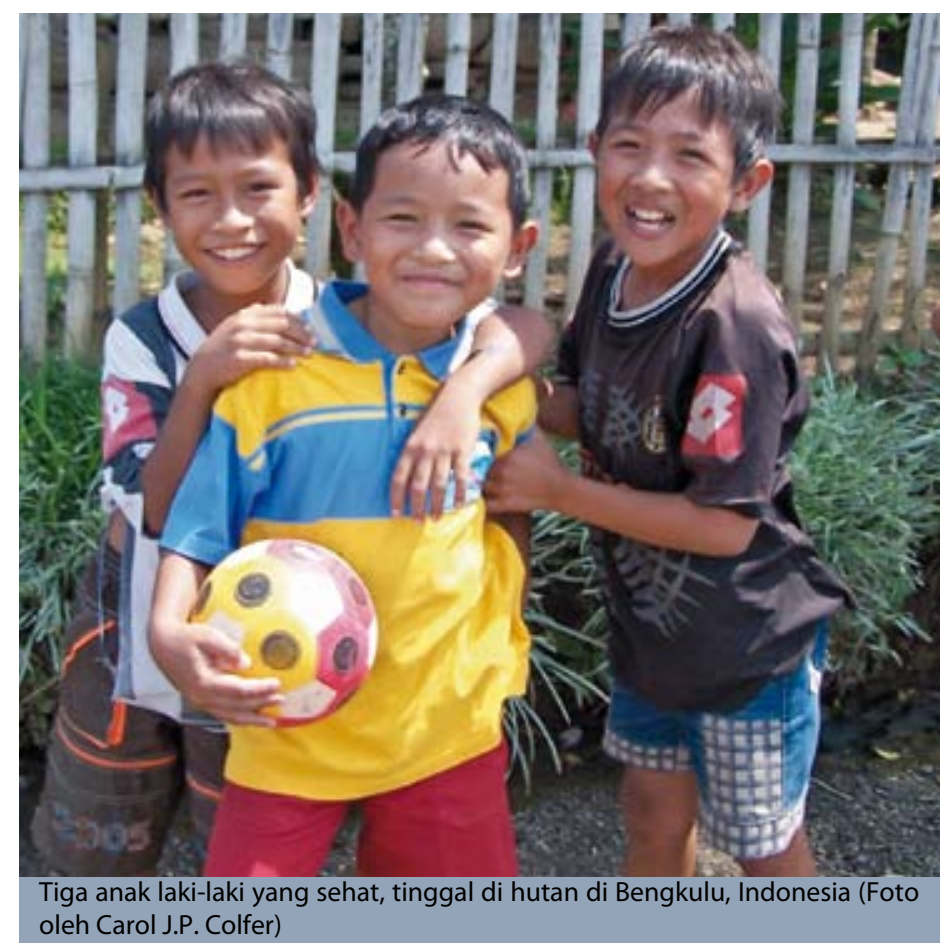

Pada beberapa kebudayaan, kaum perempuan mengalami banyak kerugian. Para praktisi kesehatan harus menjelaskan kaitan antara status perempuan dan kesehatan keluarga, dan secara khusus memberikan perhatian yang lebih bagi perempuan pada saat-saat rentan seperti kehamilan dan menyusui. Program keluarga berencana dapat memperbaiki kesehatan keluarga dan mengurangi tekanan terhadap sumber bahan pangan.

Pengelola hutan dan sumberdaya alam harus memastikan bahwa hasil hutan yang memberikan kontribusi bagi kesehatan dan kesejahteraan manusia dimanfaatkan secara bijaksana. Di antaranya, para pengelola ini harus mengembangkan rencana pengelolaan untuk melindungi tumbuhan obat-obatan. Pengelola sumberdaya juga dapat memperoleh manfaat dengan mempelajari bagaimana penduduk asli mengelola hutan secara lestari.

Para pengelola sumberdaya harus bekerjasama dengan para praktisi kesehatan dan masyarakat setempat untuk memastikan bahwa keluarga yang tergantung pada hasil hutan, termasuk masyarakat yang sangat miskin dan mereka yang menderita karena HIV/AIDS, memiliki akses terhadap sumber bahan makanan dan obat-obatan dari hutan. Perubahan dalam praktek kegiatan penebangan kayu dapat

\section{Kesehatan dan lingkungan yang harmonis}

Sebuah program baru di Kalimantan Barat mengintegrasikan layanan kesehatan masyarakat dan perlindungan terhadap lingkungan ke dalam tujuannya. Masalah lingkungan seperti deforestasi sangat berkaitan dengan meningkatnya banyak penyakit, seperti demam berdarah dan malaria, namun sedikit program kesehatan yang memperhatikan perlindungan terhadap lingkungan.

Health In Harmony, LSM Amerika, bekerjasama dengan INI RADEF (Indonesian International Rural Agriculture Development Foundation), LSM Indonesia, untuk mengimplementasikan sebuah program layanan kesehatan di desa-desa sekitar Taman Nasional Gunung Palung (TNGP). TNGP merupakan pusat perlindungan yang penting bagi orang utan dan hewan langka lainnya seperti macan tutul, siamang, dan hutan dipterokarpa dataran rendah yang terancam punah.

Program layanan kesehatan ini akan digunakan untuk meningkatkan partisipasi masyarakat dalam perlindungan daerah perbatasan TNGP dari ancaman pembalakan dan pembakaran dengan menyediakan potongan harga untuk layanan kesehatan kepada desa-desa yang tidak melakukan pembalakan dan perusakan hutan.

Menyadari bahwa masyarakat di sekitar TNGP terlalu miskin untuk membayar layanan kesehatan dengan uang, Health In Harmony juga mendukung pengembangan program-program kerja yang ramah lingkungan, seperti pertanian organik dan reforestasi. Ini akan memungkinkan pesakit atau keluarganya untuk membayar layanan kesehatan dengan bekerja, sementara meningkatkan nutrisi, mempromosikan praktek pertanian yang ramah lingkungan, dan memperkenalkan berbagai keahlian baru kepada masyarakat setempat.

Pada tahun 2007 Health In Harmony bersama INI RADEF merencanakan untuk membuka klinik yang akan diperluas menjadi rumah sakit bertenaga air pada tahun 2010. Tambahan informasi mengenai Health In Harmony dapat ditemukan di www. healthinharmony.com. 
membantu menurunkan tingkat penyebaran HIV/AIDS dengan mengatur ulang struktur kegiatan penebangan sehingga para pekerja dapat membawa keluarganya, serta mengurangi penyakit malaria dengan mencegah nyamuk berkembang biak dalam genangan air. Para pengelola sumberdaya juga harus mempertimbangkan dilakukannya analisis kondisi tanah untuk mengukur polusi kadar merkuri, serta kekurangan iodium, kalsium, zat besi, dan vitamin B12. Bila diperlukan, para pengelola ini juga harus memantau hidupan liar yang dapat menularkan penyakit.

Para perencana pembangunan harus memastikan bahwa pada saat hutan diubah pemanfaatannya, kebutuhan dasar penduduk setempat terpenuhi. Para perencana ini harus pula mempertimbangkan mata pencaharian penduduk yang hidup di hutan sebelum hutan ditebang habis untuk diganti peruntukannya. Untuk mengurang dampak negatif bagi kesehatan karena perubahan pemanfaatan lahan, para perencana diharapkan dapat mengembangkan kegiatan yang dapat membangkitkan mata pencaharian serta program pelatihan yang dibutuhkan.

Perusahaan pengembang dan farmasi harus berbagi keuntungan dengan masyarakat lokalyang pengetahuannya telah digunakan dan hutannya tereksploitasi. Pada tingkat yang lebih operasional, dengan membantu keluarga untuk beralih dari penggunaan kayu bakar ke penggunaan bahan bakar yang tidak begitu mencemari dapat memperbaiki kesehatan manusia serta hutan.

Instansi pemerintahan harus memantau meluasnya penyakit dan mengirim petugas yang terlatih ke wilayah hutan ketika diperlukan. Perusahaan yang mengeksploitasi sumberdaya hutan seperti yang terlibat dalam kegiatan penebangan kayu dan pertambangan, harus didorong atau disyaratkan untuk menggunakan cara-cara kegiatan yang ramah lingkungan. Perusahaan pertambangan harus didorong untuk membatasi penggunaan merkuri dalam pemrosesan emas.

Melindungi ekosistem hutan dapat membantu melestarikan tumbuhan dan hewan obat-obatan, serta memastikan pemanfaatan sumberdaya tersebut bagi generasi mendatang. Instansi pemerintah harus juga didorong untuk melindungi kebudayaan masyarakat hutan sebagai bagian dari upaya global untuk memelihara keragaman budaya. Namun demikian pendekatan yang universal tidak akan berjalan efektif. Pemerintah perlu menyesuaikan kebijakan dan pelayanan agar sesuai dengan kebudayaan yang berbeda-beda. Upaya yang direncanakan bersama harus dilakukan untuk memperbaiki status kelompok marjinal, termasuk kaum ibu dan anak perempuan.

\section{Untuk informasi lebih lanjut}

Infobrief ini dibuat berdasarkan Makalah Lepas CIFOR No. 45 (CIFOR Occasional Paper No. 45, Forest and Human Health: Assessing the Evidence, oleh Carol J. Pierce Colfer, Douglas Sheil dan Misa Kishi). Laporan ini mengulas secara ekstensif status kesehatan manusia di hutan dan hubungan sebab akibat antara hutan dan kesehatan manusia, dengan berfokus pada empat topik:

- Sumber makanan dari hutan: ketergantungan manusia akan sumber makanan dari hutan, kontribusi gizinya, dan masalah yang terkait dengan masalah gizi yang mempengaruhi masyarakat yang tinggal di hutan.

- Penyakit dan masalah kesehatan lainnya: HIV/AIDS, malaria, Ebola, keracunan merkuri, dan sekitar 20 penyakit tropis lainnya, serta masalah kesehatan yang terkait dengan hutan.

- Produk obat-obatan: kandungan biofisik dari berbagai spesies obat-obatan, produk hutan yang dimanfaatkan manusia, peran penyembuh tradisional, serta ulasan mengenai konflik tentang pembagian keuntungan dari obatobatan yang berasal dari hutan.

- Pemahaman dari sisi budaya tentang kesehatan manusia dalam masyarakat yang tinggal di hutan: pandangan holistik mengenai kesehatan dan kearifan tradisional setempat.

Laporan ini ditutup dengan rekomendasi kebijakan dan usulan bagi penelitian selanjutnya.

Bagi yang membutuhkan dokumen Forest and Human Health, silahkan menghubungi Nia Sabarniati di n.sabarniati@cgiar.org.

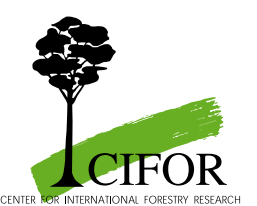

Kantor: Jalan CIFOR, Situ Gede, Sindang Barang, Bogor Barat 16680, Indonesia

Alamat surat: P.O. Box. 6596 JKPWB, Jakarta 10065, Indonesia

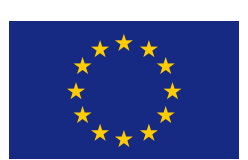

Tel: $+62(251) 622622$ Fax: +62(251) 622100

E-mail: cifor@cgiar.org Situs web: www.cifor.cgiar.org
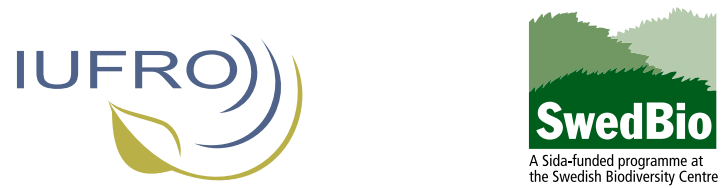

Penterjemah: Tiene Gunawan

Editor: Meilinda Wan, Yayan Indriatmoko, Linda Yuliani

Foto sampul: Miriam van Heist, Carol J.P. Colfer, Koen Kusters,

Daniel Tiveau dan Edmond Dounias 